\title{
ADAM PRZYBECKI \\ Budować wspólnotę czy administrować? Pawłowa inspiracja dla polskiego duszpasterstwa
}

Proces przeobrażeń społeczno-politycznych dokonujących się w Polsce od blisko dwudziestu lat, stanowi swoiste wyzwanie dla duszpasterstwa. Zmiana warunków działania, a przede wszystkim możliwość realizowania przez wspólnotę kościelną w sposób suwerenny własnej misji ewangelizacyjnej po blisko pięćdziesięciu latach ograniczeń wprowadzonych przez komunistyczną władzę, zmusza do postawienia na nowo pytania o to, jak być Kościołem w Polsce dzisiaj? Odpowiedź na to pytanie ma zasadnicze znaczenie w wytyczaniu głównych kierunków pastoralnej posługi, które powinien zawierać wieloletni program duszpasterski Kościoła lokalnego.

W punkcie wyjścia należy wyraźnie podkreślić, że jednym z istotnych elementów owego „być Kościołem dzisiaj”, także w Polsce, jest urzeczywistnianie go jako communio z Bogiem przez Jezusa Chrystusa w Duchu Świętym ${ }^{1}$. List Kongregacji Nauki Wiary Communionis notio z 1992 r. zwraca uwagę, że owo pojęcie kościelnej komunii musi być rozumiane $w$ kontekście całego nauczania biblijnego i tradycji patrystycznej, gdzie »komunia« zakłada zawsze podwójne odniesienie: "wertykalne" (komunia z Bogiem) $i$ »horyzontalne" (komunia mię$d z y$ ludźmi) $)^{2}$.

Podejmiemy zatem refleksję, która ukaże wspólnotę jako zasadę życia Kościoła. W jej formułowaniu ważną rolę odegrało sięgnięcie do nowotestamento-

\footnotetext{
${ }^{1}$ Por. J a n P a w e $\nmid$ I I: Adhortacja apostolska Christifideles laici. Libreria Editrice Vaticana 1988 n. 19.

${ }^{2}$ Kongregacja Nauki Wiary: List do Biskupów Kościoła katolickiego o niektórych aspektach Kościoła pojętego jako komunia Communionis notio (28 maja 1992). W: W trosce o petnię wiary. Dokumenty Kongregacji Nauki Wiary 1966-1994. Tarnów 1995 n. 3 s. 391.
} 
wego terminu ekklesia, który spotkamy w nauczaniu św. Pawła Apostoła. Następnie spojrzymy na duszpasterstwo w aspekcie budowania Kościoła-wspólnoty, by na koniec przedstawić ważniejsze przynajmniej postulaty, wynikające z takiego pojmowania pastoralnej posługi.

\section{Wspólnota jako zasada życia Kościoła}

Głównym punktem nauki o Kościele, ukazanym przez Sobór Watykański II jest eklezjologia „komunii” (communio). Zwrócił na to uwagę w odrębnym dokumencie Nadzwyczajny Synod Biskupów, zwołany przez Jana Pawła II w 1985 r. z okazji dwudziestej rocznicy zakończenia Vaticanum II. Ojcowie Synodu mówią wprost: Eklezjologia „komunii” (»communio") jest ideq centralna $i$ podstawowa w dokumentach Soboru. Pojęcie »Koinonia - communio ", oparte na Piśmie Świętym, cieszyło się w Kościele starożytnym i cieszy do dziś w Kościotach Wschodu wielkq czciq. Stą Sobór Watykański II uczynit wiele, aby Kościót byt wyraźniej rozumiany jako „komunia” i bardziej konkretnie jako „komunia” urzeczywistniany.

Co oznacza ogromnie bogate $w$ treść słowo »communio«? - pyta dalej Synod. I odpowiada: Podstawowy sens odnosi się do zjednoczenia z Bogiem przez Jezusa Chrystusa w Duchu Świętym. To zjednoczenie dokonuje się w Stowie Bożym $i$ sakramentach (»Lumen gentium «, 11). »Komunia« z Ciatem Chrystusa w Eucharystii oznacza i sprawia, czyli buduje wewnętrzne zjednoczenie (»komunię") wszystkich wiernych w ciele Chrystusa, którym jest Kościót (por. 1 Kor $10,16 n.)^{4}$.

Tuż po zakończeniu Soboru papież Paweł VI podczas jednej ze środowych audiencji wyjaśniał, że ową „komunię” należy rozumieć jako jedność z Chrystusem i $w$ Chrystusie, i jedność wśród chrześcijan w Kościele ${ }^{5}$. Do tak rozumianej tajemnicy Kościoła-wspólnoty nawiązują słowa Pawłowego pozdrowienia, które wypowiada kapłan na początku mszy św.: Łaska Pana Jezusa Chrystusa, miłość Boga i dar jedności w Duchu Świętym niech będa z wami wszystkimi (2 Kor 13, 13).

Pracom Soboru związanym z określeniem Kościoła jako communio towarzyszyła, niejako równolegle, refleksja podejmowana na terenie teologii pastoralnej,

${ }^{3}$ Kościót kierowany przez słowo Boże sprawuje Tajemnice Chrystusa dla zbawienia świata. Relacja Końcowa z Nadzwyczajnego Synodu Biskupów. „Przegląd Katolicki”. R. 74: 1986 nr 4 pkt II, C, 1 .

${ }^{4}$ Tamże.

${ }^{5}$ P a w e 1 V I: Przemówienie podczas audiencji środowej (8 czerwca 1966). W: Insegnamenti, IV (1966) s. 794 [za ChL 19]. 
której celem było pogłębienie rozumienia kościelnej komunii. Kształtowała się ona $\mathrm{w}$ ramach dyskusji, której uczestnikami byli liczni teologowie, m.in. Karl Rahner, Heinz Schuster czy Norbert Greinacher. Jednakże zasadniczą rolę odegrał w niej Ferdinand Klostermann (1911-1982), głównie poprzez pogłębione studium na temat wspólnoty. Większość uczestników wspomnianej dyskusji dochodziła do sformułowania idei Kościoła-wspólnoty opierając się na krytyce tradycyjnego ujmowania podmiotu duszpasterstwa, zacieśnionego do funkcji samych tylko kapłanów-pasterzy. Tymczasem Klostermann wyszedł od pytania o miejsce i znaczenie wspólnoty w Kościele. Opierając się na pogłębionej analizie danych Objawienia doszedł do wniosku, że wspólnota jest centralnym miejscem i istotnym elementem urzeczywistniania się Kościoła. W swych rozważaniach poszedł tak daleko, że nie wahał się stwierdzić, iż Kościół z zasady ukazuje się światu przede wszystkim jako wspólnota, a jego obecność w świecie w sposób zasadniczy jest uzależniona od wcielenia się w konkretną wspólnotę. Podkreślał, że powstanie Kościoła nie jest wtórnym procesem organizowania się pojedynczych osób, które przyjęły chrzest i bierzmowanie, ale jest procesem wnikania w konkretną wspólnotę człowieka, który w tajemnicy wiary i chrztu staje się członkiem Kościoła. Klostermann odwoływał się w tym wypadku do specyficznie chrześcijańskiego sensu pojęcia wspólnoty, wywodzącego się od nowotestamentowego terminu ekklesia. Zwracał uwagę, że w nauczaniu św. Pawła Apostoła, szczególnie w Pierwszym i Drugim Liście do Koryntian, termin ten pojawia się w poczwórnym znaczeniu. Najpierw oznacza zgromadzenie chrześcijan zjednoczonych przez słuchanie słowa, łamanie chleba i bratnią miłość. Używany jest też w odniesieniu do wspólnoty osób gromadzących się w domu „na łamaniu chlebem". Termin ekklesia określa również jedność wszystkich wyznawców Chrystusa przebywających w jednej miejscowości. Wreszcie w czwartym znaczeniu odnoszony jest do wszystkich chrześcijan, stanowiących lud Boży Nowego Przymierza.

Ferdinand Klostermann podkreślał, że dla św. Pawła wszystkie te wspólnoty są Kościołem. Muszą zatem istnieć jakieś wspólne dla tych różnych grup cechy, które określą istotne elementy tworzące Kościół Chrystusowy. Na podstawie wnikliwej analizy tekstów biblijnych doszedł do wniosku, że wspomniane wspólne cechy to: Duch Pana, słowo Pana, kult Pana i miłość Pana. Tak więc, konkludował, wspólnota w Chrystusie (koinonia en Christo), czyli Kościół jest wynikiem realizacji wyliczonych wcześniej elementów, określanych także jako

\footnotetext{
${ }^{6}$ Refleksje te zawarte zostały w pracy - F. K lo s t e r m a n n: Prinzip Gemeinde. Gemeinde als Prinzip des kirchlichen Lebens und der Pastoraltheologie als der Theologie dieses Lebens. Wien 1965. Wiener Beiträge zur Theologie. Band XI. Dalsze rozwinięcie tematyki związanej z zagadnieniem wspólnoty znaleźć można w kolejnej pracy - F. Klostermann: Gemeinde Kirche der Zukunft. Thesen, Dienste, Modelle. Bd. 1-2. Freiburg Basel Wien 1974.
} 
leiturgia, martyria i diakonia ${ }^{7}$. Oczywiście pojmowana w ten sposób wspólnota kieruje się zespołem innych jeszcze praw i właściwości, podlega kolejnym fazom rozwoju, przyjmuje różne, znane z przekazu tradycji formy swego istnienia, czy to jako wspólnota powszechna, lokalna, diecezjalna i parafialna, czy to jako mała wspólnota tworzona przez konkretne osoby.

Zwracał wreszcie uwagę, odwołując się do budowania różnych wspólnot, poprzez które dokonuje się aktualizacja Kościoła, że owo budowanie wspólnoty jest właściwym przedmiotem i zarazem podmiotem duszpasterstwa. W budowaniu wspólnoty biorą aktywny udział wszyscy jej członkowie, choć w różnym zakresie w i różny sposób, w zależności od powołania, charyzmatu, pełnionego urzędu czy święceń. Klostermann mówił wprost o wspólnocie jako zasadzie życia Kościoła (Prinzip Gemeinde) i równocześnie teologii pastoralnej rozumianej przez niego jako teologia życia Kościoła.

\section{Duszpasterstwo budowaniem Kościoła-wspólnoty}

W aktualnych publikacjach, które nawiązują do przytoczonego wcześniej stwierdzenia Synodu Biskupów z 1985 r., że eklezjologia ,komunii” (»communio «) jest ideq centralnq i podstawowa $w$ dokumentach Soboru, niejednokrotnie spotkać można bardzo krytyczne uwagi na temat jej realizacji. Dotyczy to nie tyle teologii systematycznej, co przede wszystkim teologii pastoralnej, w której nie tak łatwo dostrzec następstwa przyjęcia eklezjologii komunii. Jak podkreśla jeden z autorów - chodzi bowiem o to, czy wypracowana przez Sobór »eklezjologia communio została przyjęta przez teologie pastoralna jako zasada formalna teologii życia i działania Kościoła w świecie współczesnym ${ }^{8}$. Bez tego procesu trudno oczekiwać, aby idea ta znalazła swoje odzwierciedlenie w duszpasterstwie. Ważne dla rozumienia tej sprawy - jak pisał ks. prof. Franciszek Blachnicki - jest przekonanie, że urzeczywistnianie Kościoła jako »koinonii«, ze wszystkim, co wchodzi w istotna treść tego pojęcia, jest celem wszelkiego dziatania Kościoła. »Koinonia« jest również ostatecznym kryterium oceny adekwatności aktualnej postaci Kościoła lub jego aktualnego stanu oraz jego działania w odniesieniu do jego istoty oraz misji, zleconej mu przez Pana9.

Wspomniany teolog podjął w Polsce próbę ujęcia teologii pastoralnej i duszpasterstwa, ukazując wspólnotę (communio) jako ich zasadę. Dokonał tego uzu-

\footnotetext{
${ }^{7}$ Por. K 1 o s t e r m a n n: Prinzip Gemeinde, dz.cyt., s. 40-58.

${ }^{8}$ M. A ndrzej: Recepcja eklezjologii »communio« $w$ polskiej teologii pastoralnej. W: „Communio« w chrześcijańskiej refleksji o Kościele. Red. A. C z a j a, M. M a r c z e w s k i. Lublin 2004 s. 418.

${ }^{9}$ F. B 1 a c h n i c k i: Teologia pastoralna ogólna. Cz. 2. Eklezjologiczna dedukcja teologii pastoralnej. Lublin 1971 s. 447.
} 
pełniając o elementy spekulatywne i dedukcyjne analizy Klostermanna, który sformułował zasadę wspólnoty, odwołując się głównie do fenomenologicznego opisu i analizy danych wziętych ze źródeł Objawienia, a także danych dotyczących początków Kościoła. W związku z tym ks. Blachnicki określał duszpasterstwo jako działalność zbawczą Kościoła, która winna być sprawowana w duchu personalistycznym i uwzględniać wszystkie prawa życia osobowego, jakie znajdują się u podstaw procesu zbawczego, będącego dialogiem i spotkaniem. Ponieważ jednym $\mathrm{z}$ ważnych praw życia osoby jest możliwość realizowania się $\mathrm{i}$ rozwoju ku pełni we wspólnocie, stąd jej tworzenie jawi się jako konsekwencja i zarazem warunek rozwoju życia osoby. Prawidłowość ta - podkreślał - dotyczy również wymiaru nadprzyrodzonego istnienia osoby ludzkiej, odnajdywanego $\mathrm{w}$ Bożym planie zbawienia. Dlatego budowanie wspólnoty (communio) musi być zasadą duszpasterstwa.

Ta wspólnota tworzona przez działalność duszpasterską jest wspólnotą z Ojcem przez Jezusa Chrystusa i w Duchu Świętym. Realizuje się w Kościele w powiązaniu z innymi ludźmi, objętymi także Bożym planem zbawienia, w określonym momencie historii i w konkretnej grupie społecznej. $Z$ tego m.in. powodu całą działalność Kościoła, czyli jego funkcje należy rozpatrywać w aspekcie społecznym, czyli jako sposoby urzeczywistniania się Kościoła-wspólnoty w konkretnych wspólnotach. Kościół zatem staje się obecny przez liturgię, w której manifestuje się jako wspólnota i znak ją urzeczywistniający. Aktualizuje się przez martyrię pojmowaną jako słowo przepowiadania ściśle powiązane $\mathrm{z}$ funkcja katechumenatu, odnawiającego wspólnotę Kościoła wprowadzaniem do jego wnętrza nowych pokoleń. I wreszcie urzeczywistnia się poprzez diakonię, która jest wyrazem miłości, stanowiącej istotny przejaw życia wspólnoty chrześcijańskiej i warunkującej jej wzrost. To właśnie dzięki aktualizacji tych funkcji budowana jest wspólnota - koinonia en Christo ${ }^{10}$.

\section{Aktualizacja kościelnej komunii w nowej sytuacji społeczno-politycznej}

Zawarte w tytule pytanie: budować wspólnote czy administrować?, jest pytaniem prowokacyjnym. Nie można bowiem w tak krańcowy sposób ujmować problemu. Ma ono jednak uświadomić, że w działalności duszpasterskiej główny akcent powinien być postawiony na owo budowanie wspólnoty. Oczywiście egzystencja każdej społeczności wymaga przynajmniej minimum organizacji i działalności porządkującej czy administracyjnej. Można by zatem powiedzieć krótko - i budować wspólnotę i administrować, troszcząc się przede wszystkim o

\footnotetext{
${ }^{10}$ Por. F. B 1 a c h n i c k i: Teologia pastoralna ogólna. Cz. 1. Wstęp do teologii pastoralnej. Teologiczne zasady duszpasterstwa. Lublin 1970 s. 302-303, 348.
} 
konkretnego człowieka i jego relacje do wspólnoty. Nie usuwa to jednak dylematu, który bywa tak często naszym udziałem. Osobiste doświadczenia każdego z członków kościelnej społeczności w Polsce ukazują niezmiernie złożony obraz rzeczywistości.

W punkcie wyjścia trzeba zauważyć, że mimo upływu ponad czterdziestu lat od zakończenia Soboru Watykańskiego II, polskie duszpasterstwo zdominowane jest ciagle przez klerykalistyczne jego rozumienie. Głównego powodu takiego stanu rzeczy należy upatrywać w braku przyswojenia wypracowanej przez Vaticanum II i posoborowe nauczanie Magisterium eklezjologii komunii.

Wspomniana eklezjologia komunii i wynikająca z niej eklezjologiczna koncepcja duszpasterstwa, która w odróżnieniu od klerykalistycznej, podkreślającej wyłącznie aktywność duchowieństwa, ukazuje cały Kościół w jego pełnym osobowym składzie jako podmiot i zarazem przedmiot zbawienia. Bardziej widzi go jako wspólnotę-wspólnot, w której i dla której realizuje się urzędy, powołania, charyzmaty i posługi, niż w przeciwstawieniu duchowni - świeccy. Owa wspólnota powstaje nie jako wynik przyjętego z góry planu, ale jest owocem realizacji trzech podstawowych funkcji, tradycyjnie określanych w słowach: leiturgia, martyria $i$ diakonia. Kiedy zatem tak rozumiany Kościół spełnia wszystkie trzy funkcje, wówczas odkrywamy ze zdumieniem, niejako przy okazji, że oto jesteśmy wspólnotą-komunią. Jan Paweł II na zakończenie Roku Jubileuszowego w Liście apostolskim Novo millennio ineunte powiedział wprost: Czynić Kościót domem i szkota komunii: oto wielkie wezwanie, jakie czeka nas $w$ rozpoczynajacym sie tysiacleciu, jeśli chcemy pozostać wierni Bożemu zamystowi, a jednocześnie odpowiedzieć na najgłębsze oczekiwania świata ${ }^{11}$.

Sprawa ta zdaje się nie znajdywać szerszego oddźwięku w polskim duszpasterstwie. Nie brakuje parafii, które ciagle jeszcze - choć systematycznie rośnie liczba innych - pozostają dalekie prezentowanemu ideałowi. Traktuje się w nich laikat przedmiotowo, nie dopuszczając myśli o włączeniu świeckich wiernych w budowanie parafialnej wspólnoty. Duszpasterstwo pojmowane jako świadczenie usług, „urzędniczenie”, a nie posługa we wspólnocie i dla wspólnoty. To tylko nieliczne pozycje z katalogu, który można by poszerzyć o wiele innych spraw. Dodatkowym źródłem nieporozumień w tym względzie okazuje się kaznodziejska narracja prowadzona w soborowej poetyce, ale skrywająca nadal obce jej rozumienie Kościoła.

${ }^{11} \mathrm{~J}$ a n P a w e 1 I I: List apostolski Novo millennio ineunte. Libreria Editrice Vaticana 2001 n. $43 \mathrm{a}$. 
Kolejny problem związany jest $\mathrm{z}$ funkcjonowaniem Kościoła $\mathrm{w}$ minionym okresie komunizmu. Ówczesna sytuacja powodowała, że trudno było prowadzić normalne duszpasterstwo. Działalność pastoralna posiadała charakter głównie interwencyjny. Pojawiał się konkretny problem, często świadomie wywoływany przez władzę i stanowiący element permanentnej walki z Kościołem, wobec którego nie można było przejść obojętnie. Mobilizowano więc wszystkie siły, wielokrotnie kosztem innych obszarów duszpasterstwa, aby odeprzeć wrogi atak. Bardzo często walka ta angażowała tak dalece społeczność kościelną, że na tę zasadniczą, systematyczną działalność nie starczało już możliwości i czasu. To doświadczenie ukształtowało wśród wielu świeckich i duchownych postrzeganie aktywności Kościoła wyłącznie w taki właśnie sposób i, niestety, bywa żywe także dzisiaj. Egzystencja Kościoła w warunkach wolności znaczona jest napięciem między długimi okresami katakumbowej niemalże wegetacji i gwałtownymi przypływami aktywności. Ta ostatnia pojawia się coraz częściej w odpowiedzi na podrzucane czy sztucznie wywoływane przez różne środowiska tematy-hasła. I znowu, jak za czasów PRL-u, dokonuje się to za cenę systematycznej i długofalowej pracy duszpasterskiej.

$\mathrm{Na}$ koniec wreszcie trzeba zwrócić uwagę, że nie bez znaczenia - tym bardziej w aktualnej sytuacji ludzi wierzących - pozostaje odważna decyzja zmierzenia się z nieustannie powracającym pytaniem, jak być Kościołem w Polsce dzisiaj? Odpowiedź, przemyślana i wypracowana wspólnie przez wszystkich członków kościelnej społeczności, powinna być bardzo zwięzła, a zarazem głęboko inspirująca. Jej podstawowe zręby można by zarysować w kilku prostych i zrozumiałych dla każdego zdaniach: stawać się coraz bardziej Kościołemwspólnotą, stawać się Kościołem słowa, proroctwa i rozmowy (por. Paweł VI, Encyklika Eccelsiam suam, n. 65). Jestem świadomy wymowy tych zdań, zwłaszcza na tle stwierdzeń, jakie pojawiły się w wielkanocnym wydaniu jednego z polskich tygodników. Napisano w nim, że Kościót ma wiernych, nie ma wspólnoty. Miał wspólnote $w$ dniach żałoby po Janie Pawle II, ale z tego potencjatu niewiele urosto. Prawie natychmiast odzyly podziaty na tle politycznym. Katolicyzm polski z powrotem stat się bardziej polem walki niż wspótdziałania dla wspólnego dobra ${ }^{12}$.

${ }^{12}$ A. S z o s t k i e w i c z: Wspólnota katakumbowa. „Polityka”. R. 2009 [11.04.2009] nr 15 (2700) s. 25. 